\title{
THE REGIONAL STRUCTURE OF SERBIA ${ }^{1)}$
}

\author{
Radmila MILETIC, Marina TODOROVIC \\ Geographic Institute “Jovan Cvijic”, Serbia
}

\begin{abstract}
This paper approaches some of the characteristics of the regional development of Serbia, from the perspective of two models of territorial organization: one is governmental (administrative and statistical), and the other is functional. The imbalances in the levels of development of various territorial units of Serbia (regional disproportions) are the consequence of many structural disharmonies, material limitations, and problems with population structure, during many years, all worsened by political and economic events at the end of the twentieth century. Also, in this paper we point out the main characteristics of undeveloped regions, the criteria with which we can define them, and a typology of the municipalities inside each such region.
\end{abstract}

Key Words : Serbia, regional development, territorial organization, functional areas, undeveloped areas

\section{Introduction}

The problems of regionalization and regional development are very complex, with many dilemmas and open scientific questions. Policies of regional development, the criteria for regionalization, tendencies and possibilities for a balanced development, etc., are very intensely considered today; we see this also by the number of research papers about it. Here are some of the authors who studied various aspects of regional development: in Romania lanoş I., Vert C., in Bulgaria - Slaveikov P., Stoychev K., in Hungary - Enyedi Gy., Horvát Gy., in Slovenia - Cerne A., in Finland - Antikainen J., Vartiainen P., and this theme is found also in the research of: Kuklinski A., Scott A. J., Storper M., Hamilton F.E.I, Lundmark M., Malmberg A. and others.

The first of these refers to the explanation of the term, and concept, of regions, how large they must be, the borders between them, their content, purpose, etc. On the other hand, the regional problems, the inequality in their level of development, and generally the problems of economic, social, infrastructural, and other inequalities, are a reality which the modern world must face (Veselinovic, 2005). These problems did not bypass Serbia either. In Serbia, "the extensive (not intensive) development, the great domination of the criteria of sector over the criteria of structure and space, and the domination of local over broader (regional and national) long-term developmental aims, inevitably produced: . i) unequal development, ii) nonrational positioning of activities and population within the region, and, iii) great polarization between municipal centers on the one hand, and rural surroundings on the other hand, in the

1) The presented research results are a part of the Project of the Geographical Institute "Jovan Cvijic" of the Serbian Academy of Sciences and Arts, titled: "Modalities of Geopotentials Valorization in Undeveloped Regions in Serbia", financed by the Ministry of Science and Environmental Protection of the Republic of Serbia. 
level of development". Industrialization and its consequences (de-agrarization and urbanization, both spontaneous, without much planning), which happened during the second half of the previous century, produced great consequences in the geo-spatial structure of Serbia and caused a strong disproportion of the economic, functional and socio-demographic development, at various levels.

For many years, efforts have been made to overcome these regional disproportions in Serbia, but mostly without success. Regional development was not seen as an integral part of the entire social-economic development. Regional differences were seen in only one of their aspects, namely, the level of development, while other economic, social and even political aspects were neglected. The main idea was, to somehow arrange for a faster development of the undeveloped regions; a certain amount of financing was prepared for this, and a supportive mechanism was defined (The Strategy of Regional Development of Serbia, 2007). The aims of this regional development were defined in a generalized manner, and the talk about it was repeated for years, but the policy failed. The undeveloped regions lagged more and more behind. This approach inevitably produced a deepening of the regional and structural developmental problems. The consequences are evident today, in the space of the Republic of Serbia, because "A specific regional configuration was formed, with various developmental possibilities but also with a very deep gap" (Deric, Perišic, 1995). Much of the space of Serbia is a depopulation zone, and the resources there remain unused. At the same time, there is an over-concentration of population and economy in the developed centers, which has negative consequences in economic, social, spatial and ecological spheres.

The complexity of the inherited regional problems of the Republic of Serbia, plus the new invention, the regional "transitional poverty" (poverty because of transition) has reached such proportions, that it was imperative to start defining a new concept of regional development. In this context, the primary aim of the strategy of regional development of the Republic of Serbia ought to be a design of new institutional solutions and regulative mechanisms.

\section{The territorial organization of Serbia - administrative and functional aspects}

The notion of "region", the concept itself, has been a matter of some discussion. As mentioned by Đorđević J., Đorđević D. (1997), the idea of "region" depends on "identification, selection, and analysis of appropriate indicators, or criteria, which depends on the existence of appropriate statistical basis and documentation, but also on the ruling theoretical views and paradigms in the theory of regional development." Because the term "region" is used in various scientific and technical disciplines and approaches (geography, economy, statistics...), there are also varying definitions and criteria as how the exact borderlines between one region and the next should be determined. More details about the topic of regional development (seen from the geographical aspect) on the territory of Serbia can be seen in the papers: Vasović M., Djuric V., Radovanovic M., Stojkov B., Veljkovic A., Deric B., Perisic D., Djordjevic D., Tosic D, Tosic B., Todorovic M., Vojkovic G., Lješevic M, Miljanovic D., Grcic M. etc.

In this paper, we will emphasize the comparison of two different aspects of the territorial organization of Serbia on a meso-level: the administrative-governmental aspect, and the functional aspect.

Regionalization of Serbia seen from the aspect of administrative-territorial organizing has a long tradition. Through the history, "a zupanija, srez, okrug (district), inter-municipal regional communities are some of the patterns of territorial organizations of Serbia at the meso-level, between the highest level (the national government) and the municipal level" (Stojkov, 1997). In 
mid-1970, the constitution of Serbia was altered in such a manner that a possibility was given for the municipalities to form regions as their inter-municipal communities. Serbia consists of three parts, the Central Serbia, the province of Vojvodina in the north, and the province of Kosovo and Metohija in the south-west. In Central Serbia 9 of these inter-municipal regional communities were formed. The nine inter-municipal regional communities, or should we say "regions" were these: Belgrade as a special community, and Zajecar, Podrinjsko-Kolubarski, Juznomoravski, Podunavski, Kraljevo, Uzice (Titovo Uzice, at that time), Nis, Sumadija and Pomoravlje. And, indeed, Central Serbia was regionalized in this manner, but the "regions" so conceived did not advance as was expected: their general social development, and in particular their economic development, was disappointing. Tendencies appeared for multiplication of identical or very similar economic projects, each "region" trying to have a complete, all-inclusive, self-sufficient economy which would not have to buy or sell much to others (The Strategy of Regional Development of Serbia, 2007). What they should have done, but did not, was to specialize, each doing what they best can do, on the basis of their natural or man-made comparative advantages, and then, on this basis, to cooperate and exchange goods and services.

In the year 1991, the Serbian parliament adopted a new law, The Law about Territorial Organization and Local Self-Management. By this legislation, the Republic of Serbia was divided into 30 "districts", namely, 29 districts plus City of Belgrade. The primary aim was not regional differentiation to bolster development; the aim was to govern (each district was an extended lever of the power of the central government, each doing what they were told), but, partly, they were also economic units, and most of them were formed around a developmental center.

In this manner, districts were introduced into the system of political governance. According to Stojkov B. (1997: 56), thus was established a contour of regionalization of Serbia. The next, logical step was the adoption of the "Spatial Plan of the Republic of Serbia" (1996). Regionalization of Serbia was suggested, in this planning document, by the introduction of a system of centers (nodes; the nodal system) at a different level from the macro-regional (In the plan, the spatial differentiation (and delimitation) has not been done in precise agreement with the accepted macro-regional division. Opinions have been voiced about this discrepancy between the territories of macro-regions and the functional areas of regional centers, and also about the relationship between the macro-regions and the system of belts of development. More details in: Veljković, 2003). one (Belgrade - which is also the center of the Republic, and has international importance; and Novi Sad, Nis, Kragujevac, Uzice, and Pristina), and then regional, and sub-regional.

This Spatial Plan of the Republic of Serbia, adopted in 1996, defined the functional areas, and the intention was to achieve the following: "(a) rationalization of governance and more efficient performing of administrative functions relevant to everyday life and needs of the citizens; (b) organization of public services, more in accordance with the needs, opportunities and interests of the local communities; and (c) more efficient coordination of the activities and programs of the local communities. In accordance with a fixed set of criteria (1) the importance and role of a town (or city) in a network of settlements, 2) the importance and role of a town as a center of development, 3) rational thresholds of functions and maximal permissible radius of the gravitational zone, 4) the level of socio-economic development of various parts of the territory of Serbia, 5) morphological composition of the terrain and conditions for connecting the smaller spatial units with various links, 6) directions and zones of traditional connections between towns and settlements around them, 7) principles of equality in the distribution of regional development, as one of the strategic aims of the Spatial Plan of the Republic of Serbia,1996), 
Functional areas and districts

\begin{tabular}{|c|c|c|}
\hline $\begin{array}{l}\text { Functional areas } \\
\text { of the regional } \\
\text { systems of settle- } \\
\text { ments }\end{array}$ & The municipalities that belong to them & Districts \\
\hline \multicolumn{3}{|c|}{ The districts and of regional systems of settlements (functional areas) are the same } \\
\hline (1) Belgrade & $\begin{array}{l}\text { Barajevo, Vozdovac, Vracar, Grocka, Zvez- } \\
\text { dara, Zemun, Lazarevac, Mladenovac, Novi } \\
\text { Beograd, Obrenovac, Palilula, Rakovica, } \\
\text { Savski Venac, Sopot, Stari Grad, Cukarica }\end{array}$ & City of Belgrade (1) \\
\hline (2) Bor & Negotin, Kladovo, Bor, Majdanpek & Bor District (2) \\
\hline (3) Zajecar & Boljevac, Zajecar, Knjazevac, Sokobanja & Zajecar District (3) \\
\hline (4) Vranje & $\begin{array}{l}\text { Bosilegrad, Bujanovac, Vladicin Han, Vranje, } \\
\text { Presevo, Surdulica, Trgoviste }\end{array}$ & Pcinja District (4) \\
\hline (5) Leskovac & $\begin{array}{l}\text { Bojnik, Vlasotince, Lebane, Leskovac, Med- } \\
\text { vedja, Crna Trava }\end{array}$ & Jablanica District (5) \\
\hline (6) Krusevac & $\begin{array}{l}\text { Aleksandrovac, Brus, Varvarin, Krusevac, } \\
\text { Trstenik, Cicevac }\end{array}$ & Rasina District (6) \\
\hline (7) Cacak & Gornji Milanovac, Ivanjica, Lucani, Cacak & Moravica District (7) \\
\hline (8) Nis & $\begin{array}{l}\text { City of Nis (Nis, Niska Banja), Aleksinac, } \\
\text { Gadzin Han, Doljevac, Merosina, Razanj, } \\
\text { Svrljig }\end{array}$ & Nisava District (8) \\
\hline (9) Pirot & Babusnica, Bela Palanka, Dimitrovgrad, Pirot & Pirot District (9) \\
\hline (10) Prokuplje & Blace, Zitoradja, Kursumlija, Prokuplje & Toplica District (10) \\
\hline (11) Valjevo & Valjevo, Lajkovac, Ljig, Mionica, Osecina, Ub & Kolubara District (11) \\
\hline (12) Pozarevac & $\begin{array}{l}\text { Veliko Gradiste, Golubac, Zabari, Zagubica, } \\
\text { Kucevo, Malo Crnice, Petrovac, Pozarevac }\end{array}$ & Branicevo District (12) \\
\hline (13) Smederevo & $\begin{array}{l}\text { Velika Plana, Smederevo, Smederevska } \\
\text { Palanka }\end{array}$ & Podunavlje District (13) \\
\hline (14) Kragujevac & $\begin{array}{l}\text { Aranđelovac, Batocina, Knic, Kragujevac-city, } \\
\text { Lapovo, Raca, Topola }\end{array}$ & Sumadija District (14) \\
\hline $\begin{array}{c}\text { (15) Jagodina- } \\
\text { Cuprija- } \\
\text { Paracin }\end{array}$ & $\begin{array}{l}\text { Despotovac, Jagodina, Paracin, Rekovac, } \\
\text { Svilajnac, Cuprija }\end{array}$ & PomoravljeDistrict (15) \\
\hline (16) Sombor & Apatin Kula, Odzaci, Sombor & $\begin{array}{r}\text { West Backa District } \\
\text { (16) }\end{array}$ \\
\hline $\begin{array}{r}\text { (17) Kosovska } \\
\text { Mitrovica } \\
\end{array}$ & $\begin{array}{l}\text { Vucitrn, Zvecan, Zubin Potok, Kosovska Mi- } \\
\text { trovica, Leposavic, Srbica }\end{array}$ & $\begin{array}{r}\text { Kosovska Mitrovica } \\
\text { District (17) } \\
\end{array}$ \\
\hline (18) Pec & Decani, Đakovica, Istok, Klina, Pec & Pec District (18) \\
\hline
\end{tabular}


Functional areas and districts

\begin{tabular}{|c|c|c|}
\hline \multicolumn{3}{|c|}{ Several regional systems of settlements (functional areas) in one district } \\
\hline (19) Loznica & Krupanj, Loznica, Ljubovija, Mali Zvornik & \multirow{2}{*}{ Macva District (19) } \\
\hline (20) Sabac & Bogatic, Vladimirci, Koceljeva, Sabac & \\
\hline (21) Kraljevo & Vrnjacka Banja, Kraljevo, Raska & \multirow{2}{*}{ Raska District (20) } \\
\hline (22) Novi Pazar* & Novi Pazar , Tutin, Sjenica* & \\
\hline (23) Uzice & $\begin{array}{l}\text { Arilje, Bajina Basta, Kosjeric , Pozega, Uzice, } \\
\text { Cajetina }\end{array}$ & \multirow{2}{*}{ Zlatibor District (21) } \\
\hline (24) Prijepolje & Nova Varos, Priboj, Prijepolje & \\
\hline (25) Vrsac & Bela Crkva, Vrsac, Plandiste & \multirow{2}{*}{$\begin{array}{r}\text { South Banat District } \\
\qquad(22)\end{array}$} \\
\hline (26) Pancevo & Alibunar, Kovacica, Kovin, Opovo, Pancevo & \\
\hline \multicolumn{3}{|c|}{ Discrepancy between the size of functional areas and the size of districts } \\
\hline \multirow[t]{2}{*}{ (27) Subotica } & Backa Topola, Mali Idjos, Subotica & $\begin{array}{r}\text { North Backa District } \\
(23) \\
\end{array}$ \\
\hline & Ada, Kanjiza, Senta & North Banat District (24) \\
\hline \multirow[t]{2}{*}{ (28) Kikinda } & Kikinda, Novi Knezevac, Coka, & North Banat District (24) \\
\hline & Nova Crnja & $\begin{array}{r}\text { Central Banat District } \\
(25) \\
\end{array}$ \\
\hline (29) Zrenjanin & Zitiste, Zrenjanin, Novi Becej, Secanj & $\begin{array}{r}\text { Central Banat District } \\
(25) \\
\end{array}$ \\
\hline \multirow[t]{2}{*}{ (30) Novi Sad } & $\begin{array}{l}\text { Bac, Backa Palanka, Backi Petrovac, Beocin, } \\
\text { Becej, Vrbas, Zabalj, Novi Sad - city, Srbobran, } \\
\text { Sremski Karlovci, Temerin, Titel }\end{array}$ & $\begin{array}{r}\text { South Backa District } \\
\text { (26) }\end{array}$ \\
\hline & Indjija, Irig, Stara Pazova & Srem District (27) \\
\hline $\begin{array}{l}\text { (31) Sremska } \\
\text { Mitrovica }\end{array}$ & Pecinci, Ruma, Sremska Mitrovica, Sid & Srem District (27) \\
\hline \multirow[t]{2}{*}{ (32) Pristina } & $\begin{array}{l}\text { Glogovac, Kacanik, Kosovo Polje, Lipljan, } \\
\text { Obilic, Podujevo, Pristina - city, Urosevac, } \\
\text { Stimlje }\end{array}$ & Kosovo District (28) \\
\hline & Novo Brdo & $\begin{array}{r}\text { Kosovo - Pomoravlje } \\
\text { District(29) }\end{array}$ \\
\hline (33) Gnjilane & Gnjilane, Vitina, Kosovska Kamenica & $\begin{array}{r}\text { Kosovo - Pomoravlje } \\
\text { District (29) }\end{array}$ \\
\hline \multirow[t]{2}{*}{ (34) Prizren } & Gora, Orahovac, Prizren, Suva Reka & Prizren District (30) \\
\hline & Strpce & Kosovo District (28) \\
\hline
\end{tabular}

Source: Author's analysis, based on the publications of the Statistical Office of Republic of Serbia, and on the Spatial Plan of the Republic of Serbia (1996).

${ }^{*}$ Functional area of Novi Pazar includes not only the municipalities of Novi Pazar and Tutin, which are the Raska District, but also the municipality Sjenica, which belongs to the Zlatibor District. 
the space of the republic was organized into 34 functional areas (and each had a center, which had to be a regional center, or higher)". So, these were "nodal units, and each had to have a center and to cover the territory of at least 3 municipalities, with at least 150,000 residents (or 100,000 in a border zone or in a populationally stagnant area)". At the same time, the network of functional units would be a planned unit of a lower order, inside a unit of higher order, for which a regional spatial plan would be adopted.

The comparison involves 30 districts in Serbia (29 districts and City of Belgrade), as administrative-territorial and statistical units (18 in Central Serbia, 7 in Vojvodina and 5 in Kosovo and Metohija) and 34 functional areas (21 in Central Serbia, 8 in Vojvodina, 5 in Kosovo and Metohija) defined in accordance with the above-mentioned criteria (Tabel 1). Looking from the aspect of (dis)agreement between these two models of territorial organization of Serbia, we may draw the following conclusions:

- the territory of 18 districts and their municipalities coincides exactly with the territory of 18 functional areas, which is the regional system of human settlements (15 in Central Serbia, 1 in Vojvodina and 2 in Kosovo and Metohija),

- $\quad$ the discrepancies in extent (which territories are included, or not) exist between 12 districts and 16 functional are:

- 4 districts (3 in Central Serbia and 1 in Vojvodina) are divided each into 2 regional systems of settlements,

- the functional territory of 5 regional systems of settlements ( 3 in Vojvodina and 2 in Kosovo and Metohija) extends across the limits of their own districts, because they include different municipalities from other, neighboring districts,

- because of this, the extent of 3 other functional areas (Zrenjanin, Sremska Mitrovica, Gnjilane) has been made smaller than their own districts, which means, the functional sphere of influence of the center is smaller then it should be in accordance with the administrative-territorial principle of grouping of municipalities.

\section{Regional disparities and undeveloped areas}

Regional disproportions are interactively connected with the unbalanced structures of population, with material limitations, and with structural disharmonies lasting for many years. To this, we should definitely add the effects of political-economic events during the last decade of the $20^{\text {th }}$ century in and around Serbia - a drastic reduction of economic activity, a fall in living standards, arriving waves of refugees, etc. (Miletic, 2006).

According to the Strategy of regional development of the Republic of Serbia for the period 2007-2012 (2007), an index was used to determine the degree of development. This was the Index of Developmental Endangerment (IDE). It is a complex index, whose methodology was developed with the aim of granting direct and indirect regional support. With this Strategy, the districts became, for the first time, units of observation, and general units; the IRU points to the 5 developmental dimensions of each district - economic, demographic, educational, infrastructural, and ecological. Each of these dimensions of development is further divided into several (representative) indicators. The IDE is made up of the total of 13 indicators, and, of them, the greatest influence on the forming of the index is exerted by the economic indicators (6); demographics, education and infrastructure are represented by two indicators each, and there is only one indicator based on ecology. As the Strategy of regional development of the Republic of Serbia for the period 2007-2012 specifies, the indicators are: Indicators of the 
economic dimension of development: $S_{1}-$ GNP per capita (2005); $S_{2}$ - average earnings per employee (average 2003-2005); $S_{3}$ - employment rate (2004-2005); $S_{4}$ - unemployment rate (2004-2005); $S_{5}$ - index of development of SME per capita (2005); $S_{6}$ - the number of unemployed per 1 free job opening still unclaimed because no one has taken that job (average 2004-2005); Indicators of the demographic dimension of development: $S_{7}-$ rate of growth of the population (1971-2002); $S_{8}-$ index of ageing (how old the citizens are; 2002); Indicators of the educational dimension of development: $S_{9}-$ the achieved level of education of the young people, between 20 and 24 years of age (in 2002); $S_{10}$ - HDI (human development index, 2002-2004); Indicators of infrastructural dimension: $S_{11}$ - percentage of local and regional roads with modern road surface (with what percentage they participate in the total local and regional road surfaces (2002-2004); $S_{12}$ - PTT per 100 inhabitants (2002-2004); Indicator of the ecological dimension of development: $S_{13}$ - percentage of population with no access to water-supply system (with pipes) nor to sewerage (2004).

The IDE index was the basis of territorial differentiation of regional support given to each district. When this methodology was applied, the results showed that the differences between the various districts are $1: 6.8$ because the Jablanica district was 6.8 times more endangered developmentally (index 134\%) then the City of Belgrade whose IDE was the lowest $(19.8 \%$ ). But, when we look at the individual values of the indicators $\left(S_{1}-S_{13}\right)$, we notice two poles of development. In the above-mentioned Strategy of regional development of Serbia (2007) there is information that, of the 13 indicators going into IDE composite, Belgrade achieves maximum values $(1.000)$ in as many as 8 indexes $\left(S_{1}, S_{2}, S_{5}, S_{6}, S_{7}, S_{8}, S_{10}, S_{13}\right)$, while for the Jablanica district the majority of indicators (9 of them) are at the values between 0.000 and $0.100\left(S_{1}, S_{2}\right.$, $\left.\mathrm{S}_{3}, \mathrm{~S}_{4}, \mathrm{~S}_{5}, \mathrm{~S}_{6}, \mathrm{~S}_{7}, \mathrm{~S}_{12}, \mathrm{~S}_{13}\right)$.

According to the analysis of the levels of development a categorization and a typology of the regions was made. The undeveloped part of the Republic of Serbia includes 37 municipalities (with the total of $12.4 \%$ of the population of Central Serbia and Vojvodina, no data for Kosovo and Metohija). Inside this part of the country, two basic groups were discerned, and typology made for them (Table 2):

1) economically undeveloped areas, and,

2) areas with special developmental problems

Economic dimension of the already-achieved development of the municipalities is the basic dimension for defining an area as undeveloped. In this context, two indicators were used as the most representative for the level of development of a municipality, and, simultaneously, for structural changes: those were the national income per capita (the 2002-2004 average) and the unemployment rate (the 2004-2005 average), while an additional criterion was the drop in population (the amount of depopulation) that happened from 1971 to 2002.

As for the national income per capita (average for the years 2002 to 2004), as many as 29 municipalities had values below $50 \%$ of the average of the Republic of Serbia. These were mostly the municipalities who, for several decades now, have this "tradition" - they are "traditionally" undeveloped. On the basis of this, these municipalities were placed in the first group, the economically undeveloped areas. The main characteristics of this group are: several decades of non-development in the south of Serbia and in the south-west - the Stara Raska (municipalities of Tutin, Sjenica, Novi Pazar, Prijepolje and Priboj), plus the new kind of poverty, the transitional one. These areas are now facing a cumulative economic problems (no industry, collapse of the large systems, undeveloped small-enterprising ventures, slow process of privatization), structural problems (high unemployment) and social and demographic problems. Of these 29 municipalities, seven do not reach even one third of the average Serbian 
national income per capita, although, actually, two of the seven are industrial centers - Bor and Majdanpek. Situation is worst in two districts in the south of Serbia - Jablanica and Pčinja - in which, of the total of their 13 municipalities, as many as 10 have been given the status of undeveloped ones.

Table 2

\section{Undeveloped areas}

\begin{tabular}{|c|c|c|}
\hline & Criteria & Number of municipalities \\
\hline $\begin{array}{l}\text { 1. Economically unde- } \\
\text { veloped areas }\end{array}$ & $\begin{array}{l}\text { - national income per } \\
\text { capita }<50 \% \text { of the } \\
\text { level of the Republic } \\
\text { as a whole (average } \\
\text { for the years 2002- } \\
2004 \text { ) }\end{array}$ & $\begin{array}{l}29 \text { municipalities: Majdanpek, Presevo, } \\
\text { Bosilegrad, Medvedja, Tutin, Trgoviste, Bor, } \\
\text { Sjenica, Zagubica, Svrljig, Lebane, Crna } \\
\text { Trava, Vlasotince, Bela Palanka, Razanj, } \\
\text { Prijepolje, Novi Pazar, Krupanj, Doljevac, } \\
\text { Priboj, Bojnik, Vladičin Han, Bujanovac, } \\
\text { Varvarin, Kursumlija, Mali Zvornik, } \\
\text { Dimitrovgrad, Srem. Karlovci, Brus }\end{array}$ \\
\hline $\begin{array}{l}\text { 2. Areas with special } \\
\text { developmental prob- } \\
\text { lems }\end{array}$ & & 8 municipalities + AP Kosovo i Metohija \\
\hline $\begin{array}{l}\text { (a) demographically } \\
\text { endangered } \\
\text { areas }\end{array}$ & $\begin{array}{l}\text { - } \text { population reduced by } \\
\text { more than } 40 \% \\
\text { (during the years } 1971 \\
\text { to } 2002 \text { ) }\end{array}$ & $\begin{array}{l}5 \text { municipalities: } \\
\text { Gadzin Han, Babusnica, Zabari, Rekovac, } \\
\text { Malo Crniće }\end{array}$ \\
\hline $\begin{array}{l}\text { (b) border-zones } \\
\text { with structural } \\
\text { and demo- } \\
\text { graphic prob- } \\
\text { lems }\end{array}$ & $\begin{array}{l}\text { - population reduced by } \\
\text { more than } 20 \% \quad(1971 \\
\text { to 2002) } \\
\text { - unemployment > } 60 \% \\
\text { (average for } 2002 \text { to } \\
2004 \text { ) }\end{array}$ & $\begin{array}{l}3 \text { municipalities: } \\
\text { Nova Crnja, Sečanj, } \\
\text { Bela Crkva }\end{array}$ \\
\hline $\begin{array}{l}\text { (c) Serbian } \\
\text { municipalities } \\
\text { and } \\
\text { communities } \\
\text { inside the } \\
\text { Autonomous } \\
\text { Province } \\
\text { Kosovo and } \\
\text { Metohija }\end{array}$ & & municipalities + settlements \\
\hline Total & & $\begin{array}{l}37 \text { municipalities + Autonomous Province } \\
\text { Kosovo and Metohija }\end{array}$ \\
\hline
\end{tabular}

Source: According to Strategy of regional development of the Republic of Serbia for the period 2007-2012 (2007: 37, Tab. 16)

On the map of regional under-development, there is also the second group of the undeveloped areas - the areas with special developmental problems (eight municipalities in Central Serbia and Vojvodina + Kosovo and Metohija): intensive demographic emptying, structural problems in 


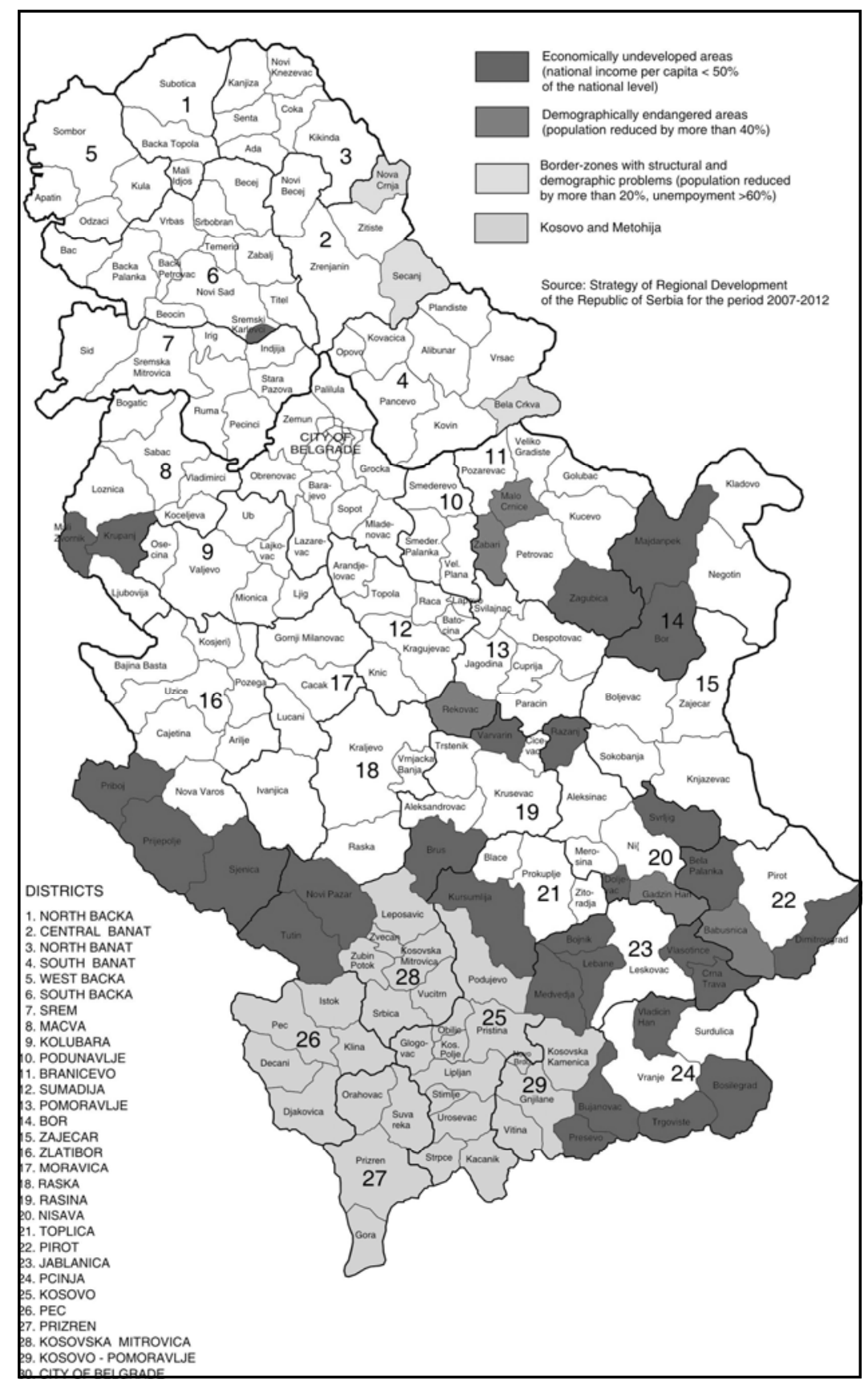

Fig. 1 - Undeveloped areas of the Republic of Serbia 
the economy, position in the border zone, and the difficult economic position of Serbian municipalities and Serbian community in the province Kosovo and Metohija. Because of their specific characteristics, this group of municipalities consists of three subgroups:

a) the first subgroup consists of the demographically endangered areas (five municipalities) in which a huge fall in the number of inhabitants, over 40\%, happened from 1971 to 2002 ,

b) the second subgroup consists of the border areas with structural and demographic problems ( 3 municipalities) in which, besides the un-adjusted economic structure and the lack of human resources, the border position is a severe limiting factor,

c) the third subgroup consists of the municipalities and the settlements in the Autonomous Province (AP) Kosovo and Metohija, where the Serbian population is in a specific, difficult economic position, and the unemployment is extremely high.

When we compare the categorization of municipalities presented in this Strategy of regional development (2007). with the categorization made by the previous Law about the Insufficiently Developed Regions of the Republic of Serbia (the Law was published in: Službeni glasnik RS, br. 35, 1995), 59 municipalities were included: 37 in Central Serbia and AP Vojvodina, and 22 municipalities in AP Kosovo and Metohija we can conclude that as many as 24 (of those 37) municipalities on the territory of Central Serbia have not altered their status.

The events in the 1990s, disintegration of the political-economic space of Yugoslavia, worsening of the conditions for economic activity because of various developmental limitations (economic isolation, undeveloped marked environment, impoverished economy, lack of investment, etc.) left a deep scar in the functioning of all parts of the economy; especially hard-hit were the extractive industry (mining) and the processing industry. Once-strong industrial centers, the regional centers of mining and traditional industry, were also in great difficulties. The status of devastated area was granted to several municipalities in eastern Central Serbia: Majdanpek, Bor, Knjazevac, Dimitrovgrad; in mid-Central Serbia, Kragujevac and Kraljevo; in western Central Serbia, Priboj, Prijepolje, Loznica; and in southern Central Serbia, Leskovac etc. Some of these municipalities were placed in the category of undeveloped areas.

\section{Closing considerations}

Regional inequalities in Serbia are of such proportions, that, obviously, the Republic needed a developmental document, in which would be clearly seen the paths towards a more balanced regional development. The Strategy of Regional Development of the Republic of Serbia for the Period 2007-2012 (2007) is the first strategic developmental document defining in a consistent and integral manner the main developmental priorities (in the area of regional development), and ways of achieving them in the coming years. According to this Strategy, the main aims and strategic directions of the regional development in Serbia are the following: "1) sustainable development, 2) increasing the competitive abilities of each region, 3) reduction of poverty and regional inequalities, 4) discontinuing the negative demographic trends, 5) continuing the process of decentralization, 6) economic integration of Serbian communities in AP Kosovo and Metohija, and 7) building-up of the institutional regional infrastructure".

According to this strategic document of the Government of the Republic of Serbia, the role of the state will be only to remove or reduce the limitations which are now constraining the life in the endangered regions. The people in those regions ought to improve their own situation, but the government should make it possible for them to achieve such auto propulsive development. This refers in particular to the areas with special developmental problems: good conditions 
should be created so that investors may arrive and that the inflow of capital may begin. Then, the threatened areas will, themselves, compensate for their own structural weaknesses.

However, the contemporary developmental-and-integration flows (globalization, sustainable development, regional integrations) and expected activities in the direction of joining the EU, demand from us that the territorial units of Serbia should be classified by a statistical methodology harmonized with the EU methodology for this. Namely, the Republic of Serbia must carry out its economic regionalization if it wants to have access to the EU funds. Into the statistical system of Serbia, a nomenclature, called NUTS, must be introduced; this will mean the European statistical standard for the gathering, processing, and presenting of the data, at the level of spatial units, the same as in the statistical system of $\mathrm{EU}^{2)}$. Especially important in this are the regional statistical data, namely, the indicators on the basis of which an assessment will be made about acceptability, when Serbia becomes a candidate for aid from the structural funds of EU. In the Strategy of Regional Development of Serbia (2007), three options have been suggested for the regionalization of Serbia.

The first version is that there should be four statistical regions NUTS 2, quite unequal in the size of their population: 1) the City of Belgrade, 2) Central Serbia (without Belgrade), 3) AP Vojvodina, (4) AP Kosovo and Metohija.

The second option for regionalization is based on a rather more equal number of people in each region (no less than 1.6 million, and no more than 2 million). In practice, City of Belgrade, AP Vojvodina and AP Kosovo and Metohija could fit into this, while the Central Serbia (without Belgrade) would be divided into two regions, about equal in population: Western Central Serbia and Eastern Central Serbia, the cities of Kragujevac and Nis being their centers.

But there is the third option, which is the most functional from the perspective of economic regionalizing so as to approach the EU funds, and also for a more precise determination of the levels of development, for the creation of regional institutions (regional developmental agencies) and statistical-analytical monitoring. The third option says that the Republic of Serbia, including its province Kosovo and Metohija, should be divided into nine economic regions - City of Belgrade (this is the same as in NUTS 2); Eastern Vojvodina (it is called Banat); Western Vojvodina (that is Bačka and Srem); Central Serbia would be divided into four regions, namely, eastern, southern, western, and middle region; and, Kosovo and Metohija would be divided into two regions, Western and Eastern. Vojvodina has its own, historic regionalization, into three regions, Srem, Banat and Backa, but, Srem is much smaller, and has a much smaller number of inhabitants, so it would not become an economic region, it would be one region with Backa.

And, finally, the creation of a new regional policy of Serbia implies also a reform and buildingup of institutions at the national, regional and local levels. The reasons for the making of this new policy are, as the Strategy... says,"(a) internal - because previous regional policies had

2) Each member-country of the EU and each country which is a candidate to join EU has already performed the NUTS 1 division into regions, and from there follows the division into NUTS 2 regions, and finally these are divided into NUTS 3 regions. The primary criterion for deciding into which NUTS category an administrative unit may be placed, is the number of inhabitants (and there are certain standards as to the proportion between the greatest and smallest permissible number of inhabitants), but there are also the following criteria: the desirable size of the territory; homogeneity of the statistical regions; naturalgeographic differences; history and tradition; and, geopolitical circumstances - the structure of the economy and the level of development of each region. 
meager effects, the aims were not achieved, regional inequalities have become even worse than before, and the local developmental potentials are not being used; (b) external - the necessity to harmonize the regional policy with the principles which must be accepted if Serbia is to join the EU and use the EU structural funds". But, the developmental regions in Serbia (the statistical regions) must develop their own innovative potentials, reduce the wasteful practices (with money) and reduce their disconnectedness, increase their own abilities to compete with each other and with the world. The main instrument for all this should be the regional developmental program, and it should be implemented in a manner that would make the investors interested. This will create the conditions needed for achieving a greater degree of the over-all functional integration of the space of the Republic of Serbia. Such integration is the main strategic direction presented in the Spatial Plan of Serbia.

\section{References}

DERIC B., PERISIC D. (1995), Teritorijalizacija regionalnog razvoja Srbije (Territorialization of regional development of Serbia), Prostorno planiranje, regionalni razvoj i zastita zivotne sredine, Posebna izdanja 26, IAUS, Beograd, p. 3-7.

DJORDEVIC J., DJORDEVIC D. (1997), Koncepti regiona i regionalizacije u planiranju $i$ neke perspektive njihove primene $u$ procesu regionalizacije Srbije (Concepts of region and regionalisation in planning and same prerequisities for their application in the regionalisation process), Geografska struktura i regionalizacija Srbije I, Zbornik radova knj. 51, Geografski institut "Jovan Cvijic" SANU, Beograd, p. 17-29.

MILETIC R. (2006), Odabrana obelezja neravnomernog regionalnog razvoja u Srbiji, (Selected indicators of uneven regional development of Serbia), Glasnik Srpskog geografskog drustva, sv. LXXXVI - 1, Beograd, p.177-190.

STOJKOV B. (1997), Drustveni iprivredni značaj regionalizacije Srbije (Social and economic importance of regioalisation of Serbia), Geografska struktura i regionalizacija Srbije I, Zbornik radova knj. 51, Geografski institut "Jovan Cvijic" SANU, Beograd, p. 53-70.

VELJKOVIC A. (2003), Tipovi regiona i njihova primena u prostornom planiranju (Types of regions nad their application in the phisical planning), Geografska struktura i regionalizacija Srbije II, Zbornik radova knj. 53, Geografski institut "Jovan Cvijic" SANU, Beograd, p. 1-30.

VESELINOVIC P. (2005), Regionalna politika u funkciji ravnomernijeg regionalnog razvoja Srbije, Regionalni razvoj i demografski tokovi balkanskih zemalja, Ekonomski fakultet, Nis , p.19-29.

X X X (1996), Prostorni plan Republike Srbije (The Spatial Plan of the Republic of Serbia), Sluzbeni glasnik Republike Srbije, Beograd.

X X X (2006), Opstine u Srbiji 2005 (Municipalities of Serbia 2005), Republicki zavod za statistiku, Beograd.

X X X (2007), Strategija regionalnog razvoja Republike Srbije za period od 2007. do 2012. godine (The Strategy of Regional Development of Serbia for the Period 2007-2012), Sluzbeni glasnik Republike Srbije, br. 21, Beograd. 